\title{
Application Analysis of Wall and Deck Numerical of Modelling Composite Ship EN AC-AISi10Mg (b)+SiC*/15p By Using ANSYS ver. 12.0
}

\author{
Tjahjanti P.H \\ Department of Mechanical Engineering, University of \\ Muhammadiyah Sidoarjo (UMSIDA) \\ Sidoarjo, Jawa timur, Indonesia \\ E-mail :pran_tasi@yahoo.com prantasi@gmail.com
}

\author{
Septia Hardy Sujiatanti \\ Faculty of Marine Technology Engineering, Institute \\ Technology of Sepuluh Nopember (ITS) \\ Surabaya,Jawa Timur, Indonesia \\ E-mail : septi@na.its.ac.id septia_hardy@yahoo.com
}

\begin{abstract}
Composite Materials AC-AlSi10Mg (b)+SiC*/15p as alternative material for ship building and has been modeled well using ANSYS software ver. 12.0. Application modeling applied in wall and deck superstructure with the result that the reduction in thickness composite ship AC-AlSi10Mg (b) $+\mathrm{SiC}^{*} / 15 \mathrm{p}$ significant enough to reduce the weight of the ship so it will reduce the size of the total water barriers experienced by ship. As a result, the thrust (powering) ship engine fixed, it will increase the speed of the ship. Conversely, if the speed of the vessel was made permanent it will lower the powering of the vessel, so the fuel consumption becomes smaller, the effect on vessel operating costs generally become more efficient.
\end{abstract}

Keywords-wall, deck, superstructure, ANSYS ver. 12.0, ship composite EN AC-AISi10Mg(b) + SiC*/15p

\section{INTRODUCTION}

ANSYS software version 12.0, was used for structural analysis using finite element method (FEM) which allows to obtain the distribution stress in construction are analyzed. Failure of a construction can be identified by using this analysis and the right at the point where the failure is shown. So it will be easier for planners to modify the construction and strengthening of the identified construction will be damage / failure of construction. This method is now widely used in construction and building ships and offshore (offshore). Actually very broad coverage of the field of this method, is not limited to steel construction (steel construction) but also on the fluid. Broadly speaking ANSYS software version 12.0 has a working system and steps in conducting its analysis. Begins with modeling, followed by meshing, boundary conditions and loading determination and analyzed.

ANSYS software version 12.0 was used to create a numerical model of the ship is made of aluminum material kind Aluminum Casting Alloy, AlSi10Mg(b) [1] a ship building material by European Nation (EN) Aluminum Casting (AC)-43100, so it is usually written with EN AC43100 (AlSi10Mg (b)). Alloy EN AC-43100 (AlSi10Mg (b)) are included in the aluminum silicon alloy that can not be non heat-treatable. In the liquid state, have a nature capable of good flow and in the freeze process almost did not happen crack [2]. The alloy is widely used as an ingredient or metal welds in aluminum alloy welding both alloy castings and wrought alloys [3].

Of ship modeling Aluminum Casting EN AC-43100 (AlSi10Mg (b) is developed with a modeling composite ship with the same matrix and reinforcement in the form of silicon carbide ( $\mathrm{SiC}$ ) composition of $15 \%$, written with EN AC-AlSi10Mg (b)+SiC*/15p [4]. The results obtained from these two types of models of the ship is numerical modeling of ship aluminum AC-43100 EN (AlSi10Mg (b)) and composite ship EN AC-43100 (AlSi10Mg (b))+SiC*/15p) has successfully demonstrated the distribution stress to the full body ship, construction of the base (bottom), and main deck, for still water and wave conditions induced. The overall results of the stress distribution in both of model numerical of ship, its value does not exceed the stress permits (sigma 0.2 ) and have a factor of safety above the minimum allowable limit, so it is safe to use.

Furthermore with using ANSYS software version 12.0, this research will analyze the application of composite materials EN AC-AlSi10Mg (b)+SiC*/15p that can use in ship building.

\section{NUMERICAL MODELING SHIP}

\section{A. Type and Sizes Ship}

Type of aluminum ship (EN AC-AlSi10Mg (b)) and composite boats (EN AC-AlSi10Mg (b)+ SiC*/15p) to be modeled numerically using software ANSYS version 12.0 is Fast Patrol Boats with length over all (LOA) is 42.0 meters. Ship size is as follows: Length over all $(\mathrm{LOA})=42.00 \mathrm{~m}$, Length between perpendiculars (LBP) $=39.00 \mathrm{~m}$, breadth (b) $=7.00 \mathrm{~m}$, height $(\mathrm{H})=4.00 \mathrm{~m}$, draft $(\mathrm{T})=1.8 \mathrm{~m}$, maximum speed $=24,0$ knot, crew of ship $=18$ person. Shape hull of Fast Patrol Boat is known as V shaped hull, especially on the front. Planning regulations adapted to use the class from the Bureau Classification Indonesia (BKI)[5].

\section{B. Lines plan}

Redrawn begins by entering keypoint coordinates obtained from autocad drawings. Keypoint coordinates are the coordinates of the first inserted lines plan followed by the coordinates accommodation deck. Keypoint formed into lines connected. 


\section{Ship structures}

Ships and its components are generally assessed for strength under critical loading condition like collision or underwater explosion. Assessment of strength is now a days based on 'Direct Strength Analysis' which eliminates any error in judgment, which may arise out of several assumptions that otherwise have to be made regarding the interaction between several structural members. The method takes into account the effect of bending, shear, and axial and torsional deformations all together [6]. The main construction material of body of ship is aluminum casting with strict requirements of the rules of wearing BKI 2010.

\section{Modeling}

The complex ship structure, which may vary from 30 to 50 meters in length: 5 to 15 meters in breadth and 3 to 10 meters in height, is modeled completely using ANSYS version 12.0. The plates are modeled using Shell 63/ Shell 43/Shell 181 Elements. The stiffeners are modeled using Beam 4/Beam 44/ Beam 188 Elements. All the pillars are modeled using Pipe elements and all other structural masses are modeled using Mass elements. This process is also automated at times with the use of ANSYS version12,0.

\section{E. Material Properties}

Determining the properties of materials to be used are taken from all the mechanical test results data for aluminum ship EN AC-43100 (AlSi10Mg (b) and composite ship (EN AC-43100 (AlSi10Mg (b))+SiC */15p) as input modeling numerical ship, which are summarized in table 1.

TABLE 1. Data for aluminum ship EN AC-43100 (AlSi10Mg (b) and composite ship (EN AC43100 (AlSi10Mg (b))+SiC */15p)

\begin{tabular}{|c|c|c|}
\hline Data & \begin{tabular}{|c|} 
Aluminum Material \\
EN AC-43100 \\
AlSi10Mg(b)
\end{tabular} & $\begin{array}{c}\text { Composite Material } \\
\text { EN AC-43100 } \\
\text { AlSi10Mg(b))+SiC*/15p }\end{array}$ \\
\hline Density & $2.703\left[\mathrm{gram} / \mathrm{cm}^{3}\right]$ & $2.904\left[\mathrm{gram} / \mathrm{cm}^{3}\right]$ \\
\hline Modulus Elastisity & $70,000[\mathrm{MPa}]$ & $98,902.44 \quad[\mathrm{MPa}]$ \\
\hline Poisson Ratio & 0.33 & 0.3 \\
\hline Tensile Strength & $173.11 \quad[\mathrm{MPa}]$ & $225.39 \quad[\mathrm{Rm}][\mathrm{MPa}]$ \\
\hline $\begin{array}{l}\text { Permit Stress } \\
\text { (sigma } 0,2)\end{array}$ & $46.54 \quad[\mathrm{MPa}]$ & {$[\mathrm{MPa}]$} \\
\hline $\begin{array}{l}\text { Ship weight } \\
\text { (thick plate } 6 \mathrm{~mm} \text { ) }\end{array}$ & 54,865 & 61,347 \\
\hline
\end{tabular}

Source: Tensile test results

\section{F. Meshing}

After the complete structure is modeled, the plates, stiffeners, pipes and masses are individually meshed. The last step to be completed before meshing the model is to set the meshing controls, i.e. the element shape, size, the number of divisions per line, etc. Selecting the various parts of the model, one by one finite element mesh is generated. The critical portions are plates with sharp corners, curvature etc. These areas can be remeshed with advance mesh control options. "Smart element sizing" is a meshing feature that creates initial element sizes for free meshing operation. Proper care has to be taken to have the control over the number of elements and hence the number of degrees of freedom associated with the structure. This is done to have a control over the solution time. However, no compromise is made on the accuracy of the results.

\section{G. Loading}

Loads are generally estimated using the classification rules or by direct hydrodynamic calculations. The loads that make ship of aluminum (EN AC-43100 (AlSi10Mg(b)) and ship of composite (EN AC-43100 (AlSi10Mg(b))+SiC*/15p) by ANSYS version12,0, experiences during its voyage can be roughly divided into two parts. Static Loads (still water)-These consists of loads, which do not vary with time, or even if they vary, the effect of time could be neglected. The hydrostatic pressure, Weights of the ship components, Cargo and Ballast loads come under this category. In addition to these wave moments and forces coming due to ship components are also considered as static loads. Wave Induced (Quasi Static)- to consider water as a series of springs linear-elastic unrelated to one another. In the numerical of model ships, the number of springs 'installed' is placed on the full body of the ship. Hence it becomes essential to consider the loads correctly and analyze the structure accordingly. Use of ANSYS version12,0 makes the process of application of load very simple and manageable, also the chances of errors in combining the loads is eliminated.

\section{H. Component Weight Displacement Ship}

Weight component displacement ship consists of Death Weight Tonnage / DWT and the weight of light weight complete of displacement weight component aluminum ship and composites ship are shown in table 2 .

TABLE 2. Loads on aluminum ships and composite Ship

\begin{tabular}{|l|c|}
\hline \multicolumn{1}{|c|}{ Death Weight Tonnage } & [Ton] \\
\hline Weight of body aluminum ship (thick 6 mm) & 54,865 \\
\hline Weight of body composite ship (thick 6 mm) & 61,347 \\
\hline Weight of machinery and electricity & \\
a. Engine room equipment & 37.49 \\
b. Pump in engine room & 2,463 \\
c. Seat of pump & 0,193 \\
d. Deck equipment & 0,35 \\
e. Air conditioning room & 0,35 \\
\hline Weight Hull Outfitting & 24,219 \\
\hline Weight Interior & 7,611 \\
\hline Weight fuel & 36.96 \\
\hline Weight freshwater & 16.2 \\
\hline Weight Crew of ship & 2.6 \\
\hline Weight Machinery and electricity part weight & \\
consists of engine room equipment, pump & \\
in engine room, seat of pump, deck equipment, & \\
air conditioning room & 40,848 \\
\hline
\end{tabular}

Source: Fast Patrol Boats 
Values for all the same weight, both for aluminum ship and ship of composite, with uniform weight distribution. The difference value in between body weight of aluminum ship and ship of composite. Body weight composite ship heavier than ship of aluminum, so the expected distribution of stress that occur are not the same between the ship of aluminum and the ship of composite.

\section{RESULT AND DISCUSSION}

Results of all the testing that there has been shown that all the elements are in good condition, there are no warning or error element element. So numeric model of composite ship shown in Figure 1.

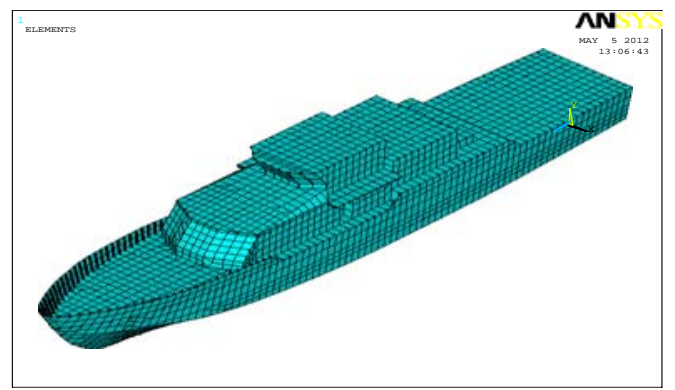

Fig 1. Numeric model of composite ship EN AC 43100(AlSi10Mg(b))+SiC*/15p)

Overall composite ship modeling EN AC 43100(AlSi10Mg(b))+SiC*/15p), shows that the stress does not exceed the value limit stress 0.2 sigma. It means that this material can actually be applied to the entire body of the ship. But because it is brittle, then the selection of applications on the ship also should look at the nature of this material. Selected applications on top of the building wall (superstructure) that the wall plate height $(\mathrm{h})=2.2$ meters and width (b) $=1.5$, composite thick ship plate is $5 \mathrm{~mm}$ (Fig. 2) and building applications on the deck plate (superstructure decks) on the size of $1 \mathrm{~m} \times 1 \mathrm{~m}$ and thickness of $6 \mathrm{~mm}$ (Fig. 3).

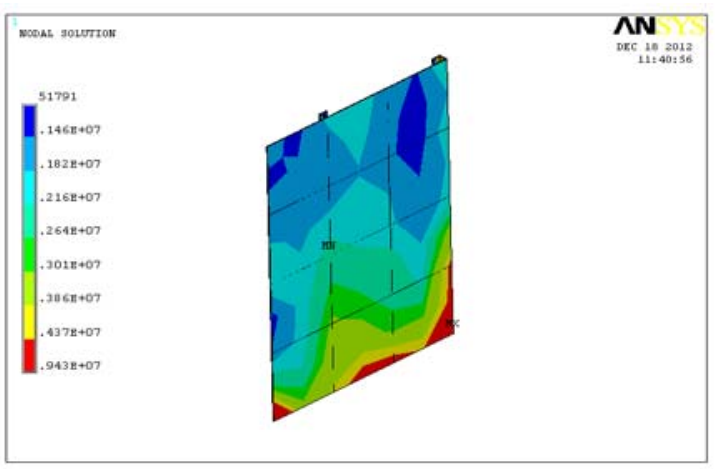

Fig 2 Distribution stress of composite ship EN AC 43100(AlSi10Mg(b))+SiC*/15p) in superstructure wall with plate thick $5 \mathrm{~mm}$ (max. stress $=9.43 \mathrm{MPa}$ )

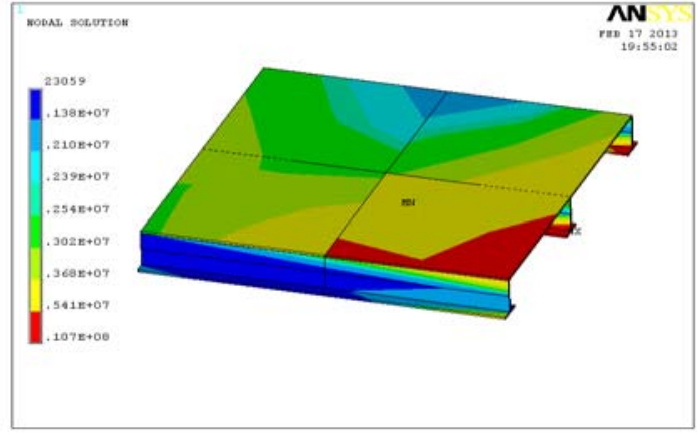

Fig 3 Distribution stress of composite ship EN AC 43100(AlSi10Mg(b))+SiC*/15p) on superstructure deck with plate thick $6 \mathrm{~mm}$ for induced wave condition $($ max. stress $=10.7 \mathrm{MPa})$

The maximum stress that occurs in ship composite EN AC 43100(AlSi10Mg(b))+SiC*/15p) for building walls on the plate thickness $5 \mathrm{~mm}$ at $9.43 \mathrm{MPa}$ and the deck superstructure with plate thickness $6 \mathrm{~mm}$ to obtain the wave-induced stress conditions maximum $10.7 \mathrm{MPa}$. Both of these results when compared with aluminum ship for the two applications (on the wall of the building) with the height and width the same, but with a thickness of $5 \mathrm{~mm}$, the maximum stress value will be 9.26 MPa (Figure 4) and for the superstructure deck of the same size but the greater thickness of $7 \mathrm{~mm}$ is obtained at $10.8 \mathrm{MPa}$ maximum stress. (figure 5). It means that the results obtained by the maximum strees between the composite ship with aluminum ship are not a significant difference, in fact it can be said the maximum stress value approaching the same value.

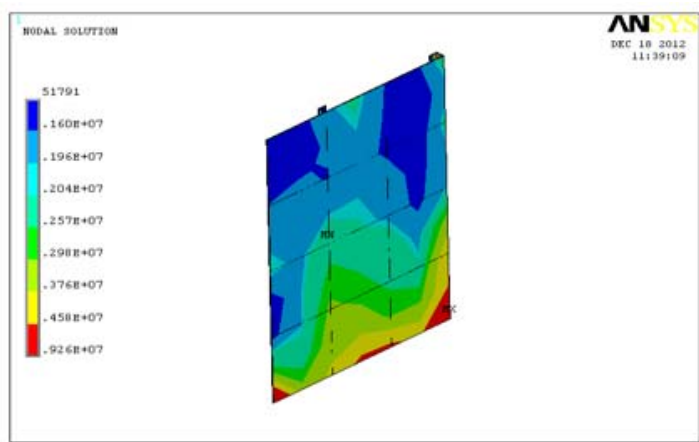

Fig 4 Distribution stress of ship aluminum EN AC-43100(AlSi10Mg(b)) with plate thick $6 \mathrm{~mm}$ (max. stress $=9.26$ $\mathrm{MPa})$ 


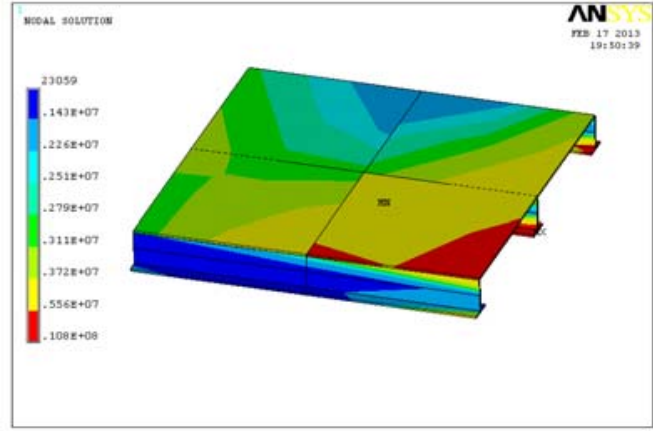

Fig 5 Distribution stress of ship aluminum EN AC-43100(AlSi10Mg(b)) on superstructure deck with plate thick $7 \mathrm{~mm}$ for induced wave condition $(\max$. stress $=10.8 \mathrm{MPa})$

Actually the main core of ship composite EN AC 43100(AlSi10Mg(b))+SiC*/15p) as an alternative material for building ships with reduced thickness is used in the composite material will impact on the weight loss, heavy displacement ship will be reduced, then for the length, width, and height of the vessel remains, laden vessel will be reduced. With a large reduction in the laden ship, the wetted surface area / WSA of the hull is submerged in water will also be reduced. This will reduce the size of the total water barriers experienced by vessels which in turn thrust (powering) ship engine fixed, it will increase the speed of the ship. Or conversely, if the desired speed of the ship is made permanent, this will lower the powering of the vessel and it will certainly reduce the relatively large ship main engine. So in general can decrease the volume of the cylinder marine engine. Thus the fuel consumption becomes smaller, thus making the vessel operating expenses generally become more efficient.

\section{CONCLUSION}

Reducing the thickness of the composite plate EN AC43100 (AlSi10Mg (b) + SiC*/15p) to be significant enough to reduce the weight of ship structure thus reducing the total water resistance experienced by the ship as a result of thrust force ship engine fixed, it will increase the speed of the ship. Conversely, if the speed of the ship is stable it will lower the thrust of force ship, so that the consumption of fuel becomes smaller, the effect on vessel operating expenses are generally becoming more efficient

Generally shipbuilding from composite materials EN AC-43100 (AlSi10Mg (b) + SiC*/15p) can be made good, by using modelling ANSYS program ver.12, 0 , used as an alternative material for ship building .

\section{ACKNOWLEDGMENT}

The authors would like to thank to the Ministry of Education and Culture National Indonesia (Kemendikbud) for grant aid BPPS scholarship and PhD Research Grants.

\section{REFERENCES}

[1] Tjahjanti P.H, Manfaat D, Nugroho W.H,Darminto, Panunggal Eko, Analisa Pemodelan Numerik Kapal Aluminum Casting EN AC43100(AlSi10Mg(b) Untuk Bangunan Kapal ,accepted for publication in Jurnal Sain dan Teknologi,BPPT, Edisi bulan Agustus 2013.

[2] Tzimas E.,Zavaliangos A.:Acta Mater 47 (1999) 517 - 528

[3] Thomas, W. M.1991 Friction Stir Butt Welding U.S. Patent No. 5, 460, 317.

[4] Tjahjanti P.H, Manfaat D, Nugroho W.H,Darminto, Panunggal Eko, 2013,“ Analysis Of Stress Distribution Model Of Numerical Of Ship Composite EN AC-43100(AlSi10Mg(b)+SiC*/15p, vol.1 no.7 (April 2013 pp 1-12)

[5] BKI (2009). Rules for the Classification and Construction of Seagoing Ships Vol II. Biro Klasifikasi Indonesia. Jakarta.

[6] Taggart, 1980, Ship Design and Construction, SNAME. 
